\title{
Resolving the "Choice-of-Law Problem" in Rule 23(b)(3) Nationwide Class Actions
}

\author{
Ryan Patrick Phair †
}

Once certain prerequisites are met, Rule 23 of the Federal Rules of Civil Procedure authorizes a discrete number of litigants to aggregate their claims and proceed as a class against a common defendant. In particular, Rule 23(b)(3) provides a special mechanism for small plaintiffs to recover damages where they would otherwise lack incentives to litigate on their own because the costs of litigation outweigh the potential value of their claims. ${ }^{2}$ Before a Rule 23(b)(3) class action may be certified, however, a federal court must ascertain whether there are common questions of law or fact that predominate amongst the class and whether the class as a whole is manageable. Recently, in the context of nationwide Rule 23(b)(3) class actions, the federal courts have struggled with these two questions. In particular, the courts have often been confounded by the "choice-of-law problem," which refers to the fact that a federal court may be obligated to apply the law of each individual class member's state of domicile to each of their individual claims respectively, thereby frustrating Rule 23(b)(3)'s twin requirements. Indeed, the federal appellate courts have created a strong presumption that certification of a nationwide Rule 23(b)(3) class action is improper on this basis. As a result, the

† B.A. 1996, Boston College; M.P.P. Candidate 2001, The University of Chicago; J.D. Candidate 2001, The University of Chicago.

1 Rule 23(a) provides that "[o]ne or more members of a class may sue or be sued as representative parties on behalf of all only if (1) the class is so numerous that joinder of all members is impracticable, (2) there are questions of law or fact common to the class, (3) the claims or defenses of the representative parties are typical of the claims or defenses of the class, and (4) the representative parties will fairly and adequately protect the interests of the class." FRCP 23(a).

2 See, for example, Amchem Products, Inc v Windsor, 521 US 591, 617 (1997) ("While the text of Rule 23(b)(3) does not exclude from certification cases in which individual damages run high, the Advisory Committee had dominantly in mind vindication of 'the rights of groups of people who individually would be without effective strength to bring their opponents into court at all."') (internal citations omitted).

3 FRCP 23(b)(3).

4 See Georgine v Amchem Products, Inc, 83 F3d 610, 627 (3d Cir 1996) (decertifying nationwide asbestos class in part because variations in state laws foreclosed Rule 23's prerequisites); Castano v American Tobacco Co, 84 F3d 734, 740 (5th Cir 1996) (decertifying nationwide class of smokers because variations in state law may affect predominance and superiority); In re American Medical Systems, Inc, 75 F3d 1069, 1089 (6th Cir 1996) (referring to a national trend decertifying nationwide class actions); Valentino $v$ Carter-Wallace, Inc, 97 F3d 1227, 1231 (9th Cir 1996) (expressing that the court is "clearly troubled ... by the problems that would arise in endeavoring to apply the varying punitive damage standards of fifty different jurisdictions"); Andrews v AT\&T Co, 95 F3d 1014, 102324 (11th Cir 1996) (decertifying nationwide class of long-distance telephone customers because of the complexity of referencing fifty sets of laws); In re Rhone-Poulenc Rorer, Inc, 51 F3d 1293, 1302 
efficiencies of proceeding as a class are lost, a large number of plaintiffs with small claims are left without an effective method of vindicating their rights, and the policies underlying Rule 23 are defeated.

This Comment challenges the modern presumption that the choiceof-law problem precludes certification of a nationwide Rule 23(b)(3) class action. Part I of this Comment lays out the choice-of-law problem in Rule 23(b)(3) nationwide class actions. ${ }^{5}$ Part II addresses Rule 23(b)(3)'s requirement that common questions of law or fact predominate and asserts that the text of the rule implies that variations in state law alone should rarely, if ever, render a class uncertifiable. In turn, Part III argues that a proper understanding of choice-of-law doctrine and modern case management techniques, as well as the policies underlying Rule 23(b)(3), can enable a district court to successfully manage a nationwide Rule 23(b)(3) class action. ${ }^{6}$ Part III.A examines two key Supreme Court decisions on choice of law and suggests that the application of a single law to the class as a whole is permissible in certain circumstances. However, if a district court cannot apply a single law because of constitutional or state choice-of-law constraints, Part III.B asserts that a district court may sever core issues, group and subclass state laws into a small number of clusters by utilizing the author's proposed "horizontal Erie doctrine," and employ the specialized verdict to try the case on the merits.

(7th Cir 1995) (decertifying nationwide class of hemophiliacs, in part, because the district court's national "amalgam" approach violated the Erie doctrine); Walsh v Ford Motor Co, 807 F2d 1000, 1011-12 (DC Cir 1986) (remanding nationwide automobile owner class action suit for determination of whether variations in state law defeat predominance). But see In re School Asbestos Litigation, 789 F2d 996, 1010-11 (3d Cir 1986) (affirming conditional certification where the variations in state law may be grouped and subclassed accordingly); In re Diamond Shamrock Chemicals Co, 725 F2d $858,861-62$ (2d $\mathrm{Cir} 1984$ ) (denying writ of mandamus to vacate class certification where the application of a single "national substantive rule" is possible).

5 This Comment focuses on nationwide federal class actions based on diversity or supplemental jurisdiction that are initiated in a single forum. The unique aspects of settlement class actions, nationwide state class actions, and federal question class actions are not considered. In addition, the choice-of-law subtleties involved in cases consolidated by the Judicial Panel on Multidistrict Litigation present much more difficult issues than normal Rule 23(b)(3) nationwide class actions and are beyond the scope of this Comment. In these consolidated cases, the Supreme Court's decision in Ferens v John Deere Co, 494 US 516, 523 (1989), requires the district court in which the cases are consolidated to apply the choice-of-law principles of each of the transferor states, thereby compounding the choice-of-law problem exponentially.

6 Some courts have experimented with the proposed tools already and the author's suggestions rely in part on this experience. Yet some of the tools, as well as the arguments advanced in support of them, are controversial and subject to legitimate criticisms by courts and commentators alike. Thus, it is important to stress that the goal of this Comment is not to advocate a global framework that may be used to overcome the modern presumption against certifying nationwide Rule 23(b)(3) class actions in all cases, but rather to offer litigants and courts as many avenues around this presumption as possible in an effort to combat the frustrating effects of the presumption on the policies underlying Rule 23(b)(3). The author's theoretical discussion of the choice-of-Iaw problem should not substitute for case-specific analysis of the propriety of a nationwide Rule 23(b)(3) class action in any given scenario. 


\section{THE CHOICE-OF-LAW PROBLEM}

A. Rule 23

Rule 23 of the Federal Rules of Civil Procedure governs class actions and is primarily designed to facilitate three policy goals. ${ }^{7}$ First, the class action mechanism is designed to achieve greater economies of scale throughout the justice system by eliminating the inefficiencies associated with litigating common issues of law and fact in separate cases across the country. ${ }^{8}$ At the same time, the class action endeavors to distribute greater justice by establishing a collective action vehicle for small plaintiffs lacking incentives to litigate on their own because the costs of litigation outweigh the potential value of their claims. ${ }^{9}$ By spreading the costs of litigation across a class, a greater number of litigants are able to pool their resources in an effort to vindicate their rights. Finally, the class action protects defendants from inconsistent obligations that may be created by varying results in different courts, and similarly, it promotes the equitable principle that similarly situated plaintiffs should receive similar recoveries.

The requirements of Rule 23 reflect these underlying policy goals. On any motion for class certification, a plaintiff must initially satisfy each of the four requirements of Rule 23(a). The plaintiff must show sufficient numerosity of class members such that joinder is impracticable; commonality of factual and legal issues; typicality of the named plaintiff's claims;

7 Benjamin Kaplan, A Prefatory Note, 10 BC Indust \& Comm L Rev 497 (1969) (noting "the dual missions of the class-action device: (1) to reduce units of litigation by bringing under one umbrella what might otherwise be many separate but duplicating actions; (2) even at the expense of increasing litigation, to provide means of vindicating the rights of groups of people who individually would be without effective strength to bring their opponents into court at all"). For a more recent and expansive view of the underlying policy goals of the class action mechanism, see Mary J. Davis, Toward the Proper Role for Mass Tort Class Actions, 77 Or L Rev 157, 168-72 (1998).

8 See Richard A. Posner, Economic Analysis of Law \$ 21.9 at 624-32 (Aspen 5th ed 1998) (analyzing efficiencies associated with the class action device).

9 The Supreme Court has consistently recognized the value of this policy goal. See, for example, Amchem Products, Inc v Windsor, 521 US 591 (1997):

The policy at the very core of the class action mechanism is to overcome the problem that small recoveries do not provide the incentive for any individual to bring a solo action prosecuting his or her rights. A class action solves this problem by aggregating the relatively paltry potential recoveries into something worth someone's (usually an attorney's) labor.

Id at 617, citing Mace v Van Ru Credit Corp, 109 F3d 338, 344 (7th Cir 1997). See also Eisen v Carlisle \& Jacquelin, 417 US 156 (1974):

I think in our society that is growing in complexity there are bound to be innumerable people in common disasters, calamities, or ventures who would go begging for justice without the class action but who could with all regard to due process be protected by it. Some of these are consumers whose claims may seem de minimis but who alone have no practical recourse for [renumeration].

Id at 185-86 (Douglas dissenting). For a general discussion of the values of small claimant class actions, see Samuel M. Hill, Small Claimant Class Actions: Deterrence and Due Process Examined, 19 Am J Trial Ad 147 (1995). 
and adequacy of representation. ${ }^{10}$ In this manner, the relative economies of scale from individual and class litigation can be compared through the numerosity factor, and the potential inefficiencies from the separate litigation of common issues across the country can be measured through the typicality and commonality requirement.

Although Rule 23(a)'s four requirements are the only prerequisites for Rule 23(b)(1) and (b)(2) class actions, ${ }^{11}$ Rule 23(b)(3) class actions are a more general form of class action to recover damages and secure judgments that bind all class members save those who have opted out. ${ }^{\text {12 }}$ The Advisory Committee Notes state that Rule 23(b)(3) class actions are designed for situations where a 23(b)(1) or a 23(b)(2) class action is unavailable, but where a class action "may nevertheless be convenient and desirable." ${ }^{13}$ Since it is solely focused on an equitable assessment of the policies underlying Rule 23 , it is primarily designed to accommodate the existence of a negative value suit. ${ }^{14}$ In Amchem Products, Inc $v$ Windsor, ${ }^{15}$ the Court noted that "[w] hile the text of Rule 23(b)(3) does not exclude from certification cases in which individual damages run high, the Advisory Committee had dominantly in mind vindication of 'the rights of groups of people who individually would be without effective strength to

10 FRCP 23(a).

11 Under these provisions there are essentially three types of class actions permissible. A Rule 23(b)(1)(A) class action is often termed an "incompatible standard" class action. It allows a class to be certified when "the prosecution of separate actions by or against individual members of the class would create a risk of inconsistent or varying adjudications with respect to individual members of the class which would establish incompatible standards of conduct for the party opposing the class." FRCP 23(b)(1)(A). Paradigm cases are suits by taxpayers to invalidate municipal actions or suits by shareholders to compel the declaration of a dividend. A Rule 23(b)(1)(B) class action is often termed a "limited fund" class action. It allows a class to be certified when there is a risk that "adjudications with respect to individual members of the class ... would as a practical matter be dispositive of the interests of the other members not parties to the adjudications or substantially impair or impede their ability to protect their interests." FRCP 23(b)(1)(B). Paradigm cases are a suit against a potentially insolvent defendant or a suit where damages arising out of an accident are limited by statute. Finally, a Rule 23(b)(2) class action is often termed an "injunctive" class action. It allows a class to be certified where the defendant "has acted or refused to act on grounds generally applicable to the class, thereby making appropriate final injunctive relief or corresponding declaratory relief with respect to the class as a whole." FRCP 23(b)(2). The paradigm cases are school desegregation and institutional restructuring cases.

12 See Benjamin Kaplan, Continuing Work of the Civil Comimittee: 1966 Amendments of the Federal Rules of Civil Procedure (I), 81 Harv L Rev 356, 375-400 (1967). The Rule 23(b)(3) class action was considered by the Advisory Commitee to be "the most adventuresome of the new types." See Kaplan, 10 BC Indust \& Comm L Rev at 497 (cited in note 7).

13 FRCP Advisory Committee Notes to Rule 23(b)(3) (1966).

14 A negative value suit is a scenario where a large number of plaintiffs lacks incentives to litigate because the costs of litigation outweigh the potential value of their claims. See, for example, Phillips Petroleum Co v Shutts, 472 US 797, 809 (1985) ("Class actions [ ] may permit the plaintiffs to pool claims which would be uneconomical to litigate individually. For example, this lawsuit involves claims averaging about $\$ 100$ per plaintiff; most of the plaintiffs would have no realistic day in court if a class action were not available.").

15521 US 591 (1997). 
bring their opponents into court at all." "'Similarly, Rule 23(b)(3) is concerned with the efficiencies that may be derived from the aggregation of individual claims. The Advisory Committee Notes state that Rule 23(b)(3) class actions encompass "those cases in which a class action would achieve economies of time, effort, and expense, and promote uniformity of decision as to persons similarly situated, without sacrificing procedural fairness or bringing about other undesirable results." ${ }^{\text {"17 }}$ Thus, a Rule 23(b)(3) class action is a highly discretionary and equitable form of class action based on an assessment of the respective policies underlying it.

The Advisory Committee added two requirements for Rule 23(b)(3) class actions. ${ }^{18}$ First, a plaintiff must establish that factual or legal issues common to the class predominate over individual issues so that the efficiencies of a class action are readily apparent." The federal courts have consistently interpreted this prerequisite to require that common issues constitute a significant part of the individual's claims. ${ }^{20}$ Second, a plaintiff must demonstrate that a class action is superior to other forms of litigation, such as individual actions or permissive joinder. ${ }^{21} \mathrm{~A}$ district court considers several factors at this juncture, ${ }^{22}$ but of these factors, the difficul-

16 Id at 617 (internal citations omitted).

17 See FRCP Advisory Committee Notes to Rule 23(b)(3) (1966).

18 Although Rule 23(b)(3)'s prerequisites are meant to inform the court's discretion, the plaintiff bears the burden of proof on each requirement. Some courts have further construed this requirement to mean that a plaintiff bears the burden of proving that variations in state law are not "insuperable obstacles" to a finding of predominance and superiority. See Walsh v Ford Motor Co, 807 F2d 1000, 1017 (DC Cir 1986). However, in some states, such as California, the defendant bears the preliminary burden of proving that forum law does not apply and conflicts in state law exist, see Larry Kramer, Interest Analysis and the Presumption of Forum Law, 56 U Chi L Rev 1301 (1989), and once the defendant submits an extensive analysis of variations in state law, the burden shifts to the plaintiff to show how the variations do not frustrate predominance and superiority. See In re Computer Memories Securities Litigation, 111 FRD 675, 684-87 (N D Cal 1986); In re Activision Securities Litigation, 621 F Supp 415,430 (N D Cal 1985); In re Seagate Technologies Securities Litigation, 115 FRD 264, 269 (N D Cal 1987); Ettinger v Merrill Lynch Pierce Fenner \& Smith, Inc, 122 FRD 177, 183 (E D Pa 1988); Margaret Hull Foundation, Inc v Atlantic Financial Management, Inc, 1987 WL 15884, *6 (D Mass 1987).

19 FRCP 23(b)(3).

20 See Watson v Shell Oil Co, 979 F2d 1014, 1022 (5th Cir 1992) ("In the context of mass tort litigation, we have held that a class issue predominates if it constitutes a significant part of the individual cases."); Jenkins v Raymark Industries, Inc, 782 F2d 468,472 (5th Cir 1986) (noting that "[i]n order to 'predominate,' common issues must constitute a significant part of the individual cases"); In re Asbestos School Litigation, 104 FRD 422, 431-32 (E D Pa 1984) (noting that when "common questions ... [are] a significant aspect of the case" certification is allowed) (citation omitted).

21 FRCP 23(b)(3).

22 FRCP 23(b)(3) reads:

The matters pertinent to the findings [of superiority] include: (A) the interest of members of the class in individually controlling the prosecution or defense of separate actions; (B) the extent and nature of any litigation concerning the controversy already commenced by or against members of the class; (C) the desirability or undesirability of concentrating the litigation of the claims in the particular forum; (D) the difficulties likely to be encountered in the management of a class action. 
ties likely to be encountered in the management of a class action have been "the most hotly contested and the most frequent ground for holding a class action is not superior." ${ }^{23}$ In this respect, the superiority/manageability analysis balances the underlying policy aim of supporting negative value suits and promoting judicial efficiency with the complexity that such an action may entail.

\section{B. Choice-of-Law Constraints}

The choice of applicable law bears heavily on a district court's analysis of whether a potential nationwide class satisfies Rule 23(b)(3)'s predominance and manageability requirements. Under Klaxon Co $v$ Stentor Electric Manufacturing Co, Inc, ${ }^{2 f}$ a federal district court, exercising diversity or supplemental jurisdiction, is bound by the Erie doctrine to apply the choice-of-law methodology of the state in which it sits. Modern choice-of-law methodologies, such as the Restatement (Second)'s most significant relationship test or analogous forms of Brainerd Currie's interest analysis, focus on a balancing of the respective interests of the relevant states in selecting the law to apply to the controversy. ${ }^{26}$ Since most of the methodologies consider a state to have a significant interest in protecting its citizens and in regulating activities within its own boundaries, they place a heavy emphasis on the plaintiff's domicile as the relevant factor in determining the applicable law. In a nationwide Rule 23(b)(3) class action, which includes domiciliaries of each of the fifty states, a district court is confronted with a scenario in which each state may have a significant interest in protecting its own citizens and ensuring compensation for the injuries suffered by them. Consequently, a district court may have sufficient reason to apply the law of each individual class member's state of domicile to each individual class member's claims.

23 See Herbert B. Newberg and Alba Conte, Newberg on Class Actions \$4.32 at 4-125 (Shepard's 3d ed 1992) (summarizing the manageability issue in class action suits). See also Theodore V.H. Mayer and Robb W. Patryk, Commentary, Class Actions in Drug and Medical Device Cases: The Trend Against Class Certification, 1997 Andrews Toxic Chemicals Lit Rep 24419 (1997) (noting that an "activist judge who sees class certification as an opportunity to make her mark or solve the world's problems will see desirability overriding difficulty; the cautious or fearful judge will see difficulty and hence no desirability").

24313 US 487, 496 (1941) (holding that "[ $t$ ] he conflict of laws rules to be applied by the federal court in Delaware must conform to those prevailing in Delaware's state courts").

25 See Erie Railroad Co v Tompkins, 304 US 64 (1938). The Erie doctrine requires a federal court exercising diversity jurisdiction to apply state law, as opposed to general federal common law, to adjudicate a controversy.

26 Although some states still follow the First Restatement and other states follow variant choice-of-law methodologies, a large majority of states follow some version of interest analysis. For a general discussion, see Symeon C. Symeonides, Choice of Law in the American Courts in 1997, 46 Am J Comp L 233, 235-66 (1998) (summarizing an annual survey of various states' choice-of-law jurisprudence). 


\section{The Tension between Modern Choice-of-Law Doctrine and} Rule 23

The tension between modern choice-of-law doctrine and Rule 23(b)(3) gives rise to the so-called "choice-of-law problem." Since a district court may have to apply the laws of each individual class member's state of domicile to each individual class member's claims, and the laws of the several states may vary considerably, a district court may reason that common questions of law do not predominate. ${ }^{27}$ Moreover, since a judge would then face the allegedly "impossible task" of instructing a jury on the nuances and intricacies of the laws of the fifty states, ${ }^{23}$ a district court may also determine that a nationwide Rule 23(b)(3) class action would be wholly unmanageable. With Rule 23(b)(3)'s twin requirements frustrated, a district court may have no choice but to deny class certification.

In Castano $v$ American Tobacco $\mathrm{Co}^{29}{ }^{29}$ the paradigmatic example of the choice-of-law problem, a nationwide class of addicted smokers brought an action against various tobacco companies and tobacco research institutes. "The plaintiffs claimed defendants "failed to inform consumers that nicotine is addictive" and deliberately "manipulated the level of nicotine in cigarettes to sustain their addictive nature." ${ }^{31}$ The plaintiffs further alleged that such conduct amounted to fraud, negligence, breach of warranty, intentional infliction of emotional distress, and a violation of consumer protection statutes, among other claims. ${ }^{32}$ The district court granted plaintiffs' motion for class certification pursuant to Rule 23(b)(3).

The Fifth Circuit reversed on the ground that the district court's cursory analysis failed to consider how variations in state law affect predominance and superiority, and consequently, the district court neglected its obligation to conduct a "rigorous analysis" of Rule 23(b)(3)'s requirements. $^{33}$ Moreover, the Fifth Circuit believed that the class could not satisfy Rule 23(b)(3)'s superiority requirement because choice-of-law difficulties would present a serious obstacle to conducting a trial on the merits. $^{34}$ Although Castano is not the catalyst of the modern trend, the

27 See note 4.

28 See, for example, In re American Medical Systems, Inc, 75 F3d 1069, 1085 (6th Cir 1996) (noting that "[i]f more than a few of the laws of the fifty states differ, the district judge would face an impossible task of instructing a jury on the relevant law").

2984 F3d 734 (5th Cir 1996).

30 Id at 737.

31 Id.

32 Id.

33 Id at 741-45. In addition, the district court had misinterpreted two key U.S. Supreme Court decisions on whether it could go past the pleadings in considering predominance. Id at 744-46.

34 Id at 748-52. The Fifth Circuit also believed that superiority could not be established because class certification would create settlement pressure on the tobacco companies. In addition, the 
comprehensiveness of the Fifth Circuit's opinion has presented the federal courts with a towering precedent that has been consistently used to resist certification of Rule 23(b)(3) nationwide class actions on choice-oflaw grounds, and as a result, a strong presumption has taken root in the case law.

\section{Proposed Solutions}

Several legislative proposals have been proffered to resolve the choice-of-law issue, including the enactment of national legal standards $^{35}$ and the American Law Institute's proposed adoption of a uniform federal choice-of-law rule. ${ }^{36}$ Yet Congress has remained hesitant to enact national legislation in an area that raises such difficult issues of comity, federalism, and congressional power. ${ }^{37}$

Fifth Circuit noted that an "immature" mass tort class action necessitates a prior track record of trials from which a district court can draw on the information necessary to consider superiority; the speculative nature of the claim that a crippling judicial backlog of individual cases would result from decertification; the novelty of the addiction-as-injury theory of liability; and a wide range of other reasons. At the same time, however, the Fifth Circuit noted that "[ $\mathrm{t}]$ he most compelling rationale for finding superiority in a class action - the existence of a negative value suit-is missing in this case," which may imply that the superiority analysis may have produced a different result if the case had been a negative value suit. Id at 748 .

35 See American Law Institute, Complex Litigation Project-Proposed Final Draft 375 (1993) ("Complex Litigation Project") (recognizing that "the most direct way to attempt to solve the issues posed [is] to adopt national standards to govern the conduct of individuals or entities who are engaging in activity having interstate effects and who now are controlled by multiple, sometimes conflicting, state laws"). For example, Congress could enact a federal law of product liability to resolve the problem. See, for example, Friedrich K. Juenger, Mass Disasters and the Conflict of Laws, 1989 U IIl L Rev 105, 121-27 (proposing a new conflicts of law rule for multistate products liability claims); Russell J. Weintraub, Methods for Resolving Conflict-of-Laws Problems in Mass Tort Litigation, 1989 U Ill L Rev 129, 141-44 (advocating the adoption of a uniform liability law to remove conflicts of law problems from mass torts).

36 The ALI's Complex Litigation Project has recommended the adoption of a "coherent and uniform federal choice of law code" for complex federal court litigation on grounds of equity and efficiency. See Complex Litigation Project at 375 (cited in note 35). Recently, Senator Orrin Hatch has introduced the Judicial Improvements Act of 1999, S 248, 105th Cong, 2d Sess (Jan 19, 1999), which provides for comprehensive class action reform, including a provision incorporating the ALI's proposal to federalize choice of law. However, like similar efforts in the past, Senator Hatch's proposal has languished in the judiciary committee.

37 See, for example, P. John Kozyris, Values and Methods in Choice of Law for Products Liability: A Comparative Comment on Statutory Solutions, 38 Am J Comp L 475, 477-78 (1990) (noting persistent and unsuccessful efforts by federal legislators to pass interstate products liability law and citing articles). Moreover, in particular, the ALI's proposal has been the subject of a heated constitutional debate amongst scholars. In effect, the ALI's proposal asks Congress to do what the Supreme Court will not-overrule Klaxon. See Complex Litigation Project at 382 (cited in note 35) (suggesting that the Commerce Clause, Full Faith and Credit Clause, and Judicial Power Clause, as implemented by the Necessary and Proper Clause, support Congressional adoption of the ALI proposal); Paul S. Bird, Note, Mass Tort Litigation: A Statutory Solution to the Choice of Law Impasse, 96 Yale L J 1077, 1091-94 (1987) (Full Faith and Credit Clause); Jonathan R. Macey and Geoffrey P. Miller, A Market Approach to Tort Reform Via Rule 23, 80 Cornell L Rev 909, 910 (1995) (Commerce Clause); Douglas Laycock, Equal Citizens of Equal and Territorial States: The Constitutional Foundations of Choice of Law, 92 Colum L Rev 249, 251 (1992) (Privileges and Immunities and Full 
In addition, there have been several controversial judicial efforts and scholarly proposals that endeavor to apply a single law to the class as a whole to overcome the choice-of-law problem. ${ }^{38}$ First, in In re School Asbestos Litigation, ${ }^{39}$ the Third Circuit alluded to the possibility of applying the law of the most restrictive state to the class. ${ }^{40}$ Second, in In re Bendectin Litigation, the Sixth Circuit attempted to establish a form of consent theory by allowing the parties to opt-in to a class action that would be governed by a particular state's law. Third, at least one district court has applied a "national consensus" law to overcome the predominance and manageability concerns of nationwide Rule 23(b)(3) actions.

Faith and Credit Clauses). But see Linda S. Mullenix, Federalizing Choice of Law for Mass-Tort Litigation, 70 Tex L Rev 1623,1636 (1992) (suggesting that the ALI proposal may be unconstitutional because a federalized choice-of-law regime "effectively means that the Commerce Clause, the Full Faith and Credit Clause, and the Judicial Power Clause trump the 10th Amendment").

38 Since the author believes that these proposals are deeply flawed for reasons suggested herein, they are not advocated by this Comment. However, for a general discussion of these approaches, see Jay Tidmarsh and Roger H. Trangsrud, Complex Litigation and the Adversary System ch 7 at $\&$ B (Foundation 1998).

$39977 \mathrm{~F} 2 \mathrm{~d} 764$ (3d Cir 1992).

40 Id at 796-97 (instructing the district judge on remand to examine the Shutts decision carefully before submitting the case to the jury according to the law of the most restrictive state). Although the issue has not been decided, it seems clear that the Shutts decision would foreclose such a possibility, unless the most restrictive state happened to be a state that had significant contacts or an aggregation of contacts with the litigation so as to render the choice of law neither arbitrary nor unfair. In addition, the application of the law of the most restrictive state would blatantly ignore the Klaxon analysis of state choice-of-law methodology. See Part III.A.

$41857 \mathrm{~F} 2 \mathrm{~d} 290,295,302-03$ (6th $\mathrm{Cir} 1988$ ) (upholding the district court's offer of the right to opt in to a class action under Ohio law to consolidated parties).

42 Id at 295, 302-03. However, in the Bendectin litigation, Merrell Dow Pharmaceuticals, the manufacturer of Bendectin, was headquartered in Ohio-the forum state. As noted in Part III.A, the Shutts test authorizes the selection of a single state's law in such circumstances, which may suggest that the opt-in procedure cannot be accomplished independent of that primary analysis. Moreover, as also noted in Part III.A, a district court may not select a single state's law independent of the Klaxon analysis of state choice-of-law methodologies. The opt-in procedure may run afoul of this aspect of the choice-of-law analysis. For example, a state's interest in protecting its domiciliaries may not be realized if an individual opts in to a disadvantageous class action, perhaps at the urging of an entrepreneurial plaintiff's attorney.

43 In In re "Agent Orange" Product Liability Litigation, 506 F Supp 737, 744-46 (E D NY 1979), the court attempted to assert federal common law to govern a nationwide class of persons exposed to Agent Orange, but the Second Circuit overturned the assertion. See In re "Agent Orange", $635 \mathrm{~F} 2 \mathrm{~d}$ 987, 995 (2d $\mathrm{Cir} 1980$ ). On remand, Judge Weinstein, a leading scholar on the issue of choice of law in nationwide class actions, resolved the choice-of-law problem by determining that each of the states would look to the application of a "national consensus" law of manufacturer liability, government contractor defense, and punitive damages. In crafting this solution, he relied on the strong national interest in the Agent Orange litigation. See In re "Agent Orange" Product Liability Litigation, 580 F Supp 690,711-13 (E D NY 1984). The Second Circuit denied the defendant's petition for a writ of mandamus, emphasizing Judge Weinstein's declared intention to create subclasses if difficulties arose in applying a "national consensus" law. In re Diamond Shamrock Chemicals Co, 725 F2d 858, 861 (2d Cir 1984).

Although the Supreme Court refused to grant certiorari in the Agent Orange litigation, see Diamond Shamrock Chemicals Co v Ryan, 465 US 1067 (1984), the distinction between federal common law and national consensus law is somewhat questionable. See Stanley E. Cox, Razing Conflicts Facades to Build Better Jurisdiction Theory: The Foundation-There is No Law But Forum Law, 28 
Finally, scholars relying on the Supreme Court's decision in Miree $v$ DeKalb County, ${ }^{44}$ which stands for the proposition that federal common law may be used to resolve cases involving peculiarly important federal interests, have advocated the application of federal common law to the choice-of-law determination in nationwide class actions. ${ }^{45}$ Nevertheless, despite all of these efforts, the Supreme Court has yet to provide any clear guidance on the issue. ${ }^{46}$ Consequently, the district courts have rou-

Valp U L Rev 1, 41 n 109 (1993) (arguing that Judge Weinstein "blurred distinctions" and "misinterpreted the laws of the sovereigns he was supposed to construe in order to reach a result he found more palatable"); Mullenix, 70 Tex L Rev at 1635 (cited in note 37) (suggesting that the difference between national consensus law and federal common law is merely semantic). Indeed, the Reporters for the ALI's Complex Litigation Project rejected the national consensus approach because of federalism constraints and state interests. See Complex Litigation Project at 423 (cited in note 35).

Moreover, the Agent Orange litigation involved extraordinary circumstances and an unusually strong national interest. Therefore, it may be limited to its facts. See, for example, Jackson v JohnsManville Sales Corp, 750 F2d 1314, 1323-27 (5th Cir 1985) (refusing to apply federal common law in asbestos litigation because of the lack of a uniquely federal interest). See also In re Joint Eastern and Southern District Asbestos Litigation, 129 Bankr L Rptr (CCH) 710,871 (E D NY 1991) (noting that, in general, the safer road is one that recognizes states' interest in applying their own substantive law). Finally, as Judge Weinstein himself recognized, the Supreme Court warned in Day \& Zimmermann, Inc v Challoner, 423 US 3 (1975), that the Klaxon analysis should not "yield to the more modern thinking of [choice-of-law] scholars." In re "Agent Orange" Litigation, 580 F Supp at 693 (internal citations omitted).

44433 US 25, 31 (1977) ("In deciding whether rules of federal common law should be fashioned, normally the guiding principle is that a significant conflict between some federal policy or interest and the use of state law ... must first be specifically shown."), quoting Wallis $v$ Pan American Petroleum Corp, 384 US 63, 68 (1966). See also Kohr v Allegheny Airlines, Inc, 504 F2d 400, 403 (7th Cir 1974) (holding that federal common law governed contribution and indemnity in litigation resulting from midair collision between commercial and private airplanes); Northwestern Airlines, Inc $v$ Transport Workers Union of America, AFL-CIO,451 US 77,90-91 (1981) (citing Kohr and recognizing the possibility of a federal common law of contribution).

45 See Steven L. Schultz, In re Joint Eastern and Southern District Asbestos Litigation: Bankrupt and Backlogged-A Proposal for the Use of Federal Common Law in Mass Tort Class Actions, 58 Brooklyn L Rev 553, 609 (1992) (arguing that asbestos litigation meets the federal common law standard of "where "the interstate ... nature of the controversy makes it inappropriate for state law to control"'), quoting Texas Industries, Inc v Radcliffe Materials, Inc, 451 US 630, 640 (1981); Macey and Miller, 80 Cornell L Rev at 911 (cited in note 37); Georgene M. Vairo, Multi-Tort Cases: Cause for More Darkness on the Subject, or a New Role for Federal Common Law?, 54 Fordham L Rev 167, 172-73 (1985) (arguing that federal common law should be applied in national mass tort cases). But see Mullenix, 70 Tex L Rev at 1635 (cited in note 37) ("In short, the legal profession has a longstanding, collective psychological block with regard to even the mention of federal common law, and its occasional messengers are typically received with polite disregard."); Andreas F. Lowenfeld, Mass Torts and the Conflict of Laws: The Airline Disaster, 1989 U III L Rev 157, 170 (finding the notion of a federal common law of choice of law "quite hopeless").

46 Although the Court has delineated the constitutional dimension to choice of law in nationwide class actions, see Part III.A, it has not resolved the more difficult Klaxon issue within that constraint and that issue's relation to Rule 23. For a discussion of the Supreme Court's reluctance to decide this issue, see Louise Weinberg, Choice of Law and Minimal Scrutiny, 49 U Chi $\mathrm{L}$ Rev 440 (1982) (suggesting that the Court's impossible caseload of arguably greater significance means that it simply lacks the time to fashion the necessary law to elaborate a significant and coherent constitutional theory of choice of law in nationwide class actions); Bird, Note, 96 Yale L J at 1078-79 (offering additional explanations of the lack of guidance from the Court). Moreover, in the absence of such guidance, the district courts have been reluctant to innovate because of the fear that a nationwide class action may take many years, perhaps even a decade to litigate. Thus, a common defense tactic 
tinely conformed to the prevailing presumption in the federal appellate courts and denied most attempts to certify nationwide Rule 23(b)(3) class actions. As a result, the efficiencies of proceeding as a class are lost, a large number of plaintiffs with small claims are left without an effective method of vindicating their rights, and the policies underlying Rule 23 are defeated.

\section{OVERCOMING THE PREDOMINANCE REQUIREMENT}

Any analysis of the choice-of-law problem in Rule 23(b)(3) nationwide class actions should begin with the text of Rule 23 itself. On a motion for class certification pursuant to Rule 23(b)(3), the plaintiff bears the burden of proving that a potential nationwide class action raises common questions of law or fact that predominate over any individual questions. ${ }^{47}$ Many federal district courts are troubled by predominance issues in nationwide Rule 23(b)(3) class actions on choice-of-law grounds because of the federal appellate courts' strong presumption that the lack of common issues of law cannot be overcome. ${ }^{28}$ In Castano, the Fifth Circuit, assuming the laws of the fifty states were applicable, believed that the resulting disparity in legal issues magnified the potential factual differences exponentially, thereby swamping the class with individual issues and defeating predominance. It may be, however, that the federal appellate courts have neglected the text of the rule itself. Indeed, it has been nearly two decades since the Illinois Supreme Court, in Miner v Gillette $\mathrm{Co}$, made the simple but frequently overlooked observation that Rule 23(b)(3)'s predominance requirement is phrased in the disjunctive, not

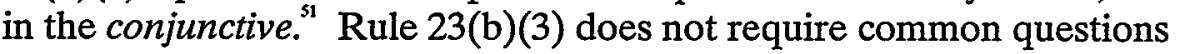
of law and fact to predominate; it requires that common questions of law or fact predominate. Thus, if common questions of fact predominate, but common questions of law do not, a district court should not refuse class certification on predominance grounds based on the choice-of-law problem alone.

\footnotetext{
on motions for class certification has been to trot out a parade of horribles highlighting the potential length and complexity of a nationwide class action. See Sheila Birnbaum, et al, How to Prevail in the Class Certification Battle: Strategies for Defendants, paper presented at American Bar Association, National Institute on Class Actions (June 12,1998), available on Westlaw at N98CACB ABALGLED E-1, and since most class actions settle before trial, the reality has never been tested.

47 FRCP 23(b)(3).

48 See note 4.

$4984 \mathrm{FBd}$ at $742-45$

50 87 Ill 2d 7, 428 NE2d 478 (1981).

51428 NE2d at 483. Although the Illinois Supreme Court was interpreting the Illinois class action statute, the statute's language mirrored Rule 23.

52 Indeed, in Amchem Products, Inc $v$ Windsor, 521 US 591 (1997), the Court recently stated in a somewhat related context that the federal courts "must be mindful that [Rule 23] sets the requirements they are bound to enforce. Federal rules take effect after an extensive deliberation process involving many reviewers: a Rules Advisory Committee, public commenters, the Judicial Con-
} 
The importance of this simple insight bears tremendously on the prospects of a potential nationwide class. In Amchem Products, Inc $v$ Windsor, the Supreme Court noted that "[p]redominance [of fact] is a test readily met in certain cases alleging consumer or securities fraud or violations of the antitrust laws.... Even mass tort cases arising from a common cause or disaster may, depending upon the circumstances, satisfy the predominance [of fact] requirement." Indeed, "the modern mass tort cases tend to be product liability actions in [] which common questions of [fact regarding] defective design and failure to warn may more readily predominate over questions of individual use and damage."ss Therefore, if common questions of fact routinely predominate in nationwide Rule 23(b)(3) class actions, the choice-of-law problem with respect to predominance is marginalized.

Conversely, where neither common questions of law nor fact predominate, there would be no efficiencies to be gained by proceeding as a class. A nationwide Rule 23(b)(3) class action would become essentially a consolidation of thousands of individual trials with varying factual and legal scenarios. Accordingly, a district court may properly refuse class certification in such cases. However, as noted above, the class of cases in modern complex litigation where neither common questions of law nor fact predominate may be quite small.

\section{Managing A Nationwide RUle 23(B)(3) Class ACtion}

Since the choice-of-law problem is likely to create predominance objections only in rare cases, the crux of the choice-of-law problem must be rooted in Rule 23(b)(3)'s manageability requirement. In Castano, ${ }^{56}$ the Fifth Circuit stated that the choice-of-law problem may render class certification "ipso facto" improper on manageability grounds. ${ }^{57}$ The Fifth Circuit's underlying assumption was that any differences or nuances in the laws of the fifty states are per se unmanageable. As a result, the district courts, citing Castano, have routinely denied certification of nationwide classes by merely highlighting a small, random hodge podge of variations in state law, thereby avoiding the duty to conduct a rigorous analysis. $^{\text {s8 }}$

ference, this Court, Congress .... [T] he text of a rule thus proposed and reviewed limits judicial inventiveness. Courts are not free to amend the rule." Id at 620.

53521 US 591 (1997).

54 Id at 625.

55 See Jeffrey W. Stempel, Contracting Access to the Courts: Myth or Reality? Boon or Bane?, 40 Ariz L Rev 965,983 n 71 (1998) (suggesting that access to courts has diminished and assessing the systematic consequences thereof).

$56 \quad 84 \mathrm{~F} 3 \mathrm{~d} 734$.

57 Id at 750.

58 See note 4. 
The most common and problematic manageability concern is the "impossible task of instructing a jury on the relevant law (the law of fifty different states)." A nationwide Rule 23(b)(3) class action "would require the jury not only to assimilate and analyze all of the complicated testimony in each case, but also to apply their factual findings to a host of complex legal principles within each issue and each case.." As Judge Posner recently stated, state laws may vary in nuance, "[b]ut nuance can be important," and it is widely believed that a district court would have to instruct a jury on such intricacies. Consequently, a district court must have a method of mitigating such jury difficulties before certifying a nationwide Rule 23(b)(3) class action.

There are, however, several methods of overcoming the management difficulties created by the choice-of-law problem in nationwide Rule 23(b)(3) class actions. For example, in certain circumstances, a federal court may be able to apply a single law to the class as a whole. Alter-

59 In re American Medical Systems, Inc, 75 F3d 1069, 1085 (6th Cir 1996). It is important to note, however, that a jury trial may not be required in the first instance. Since the Seventh Amendment's language "preserves" the right to a jury as it existed at common law, US Const Amend VII, some modern courts, relying on a footnote in the Supreme Court's landmark decision in Ross $v$ Bernhard, 396 US 531, 538 n 10 (1970), have suggested that the Seventh Amendment does not guarantee the right to a jury trial in modern complex civil litigation. Indeed, courts have split regarding the complexity exception to the Ross footnote. Compare In re Japanese Electronic Products Antitrust Litigation, 631 F2d 1069, 1090 (3d Cir 1980) (vacating lower court's order of jury trial and remanding for consideration of complexity of prospective trial); In re Boise Cascade Securities Litigation, 420 F Supp 99,104-05 (W D Wash 1976) (holding that the Seventh Amendment did not require a jury trial in a complex securities fraud case); Bernstein $v$ Universal Pictures, Inc, 79 FRD 59,70 (S D NY 1978) (striking plaintiff's jury demand in a long and complex trial), with In re United States Financial Securities Litigation, 609 F2d 411, 426 (9th Cir 1979) (holding that Ross does not establish a functional interpretation of the Seventh Amendment); Barber $y$ Kimbrell's, Inc, 577 F2d 216, 225 n 25 (4th $\mathrm{Cir} 1978$ ) (stating that issues in class action were not so complex that they could not be effectively and efficiently decided by a jury).

In addition, some modem legal scholarship seems to support a complexity exception to the right to a jury trial. See, for example, Joseph C. Wilkinson, Jr., et al, A Bicentennial Transition: Modern Alternatives to Seventh Amendment Jury Trial in Complex Cases, $37 \mathrm{Kan}$ L Rev 61, $65-67$ (1988) (summarizing views of critics of jury trials in complex cases); Warren E. Burger, Thinking the Unthinkable, 31 Loyola L Rev 205,207-09 (1985) (pondering question of whether increasingly complex civil trials will necessitate fundamental structural changes in juries); James S. Campbell and Nicholes Le Poidevin, Complex Cases and Jury Trials: A Reply to Professor Amold, 128 U Pa L Rev 965 (1980) (analyzing colonial American attitudes and early modern English cases to suggest that complex cases were not always put before juries). But see Morris S. Annold, A Historical Inquiry into the Right to Trial by Jury in Complex Civil Litigation, $128 \mathrm{U}$ Pa L Rev 829, 848 (1980) (arguing that there "seems to be no good historical foundation for the argument that plaintiffs may be denied the right to a jury trial because their cases are complex").

If a jury is not required, then the manageability analysis should be focused on the judge's ability, as the trier of fact, to ascertain the meanings of the laws of the fifty states and apply a given set of facts to them in reaching a verdict. Yet, the proposition remains highly controversial, and as such, a district court should consider its applicability with some skepticism. Of course, under Rule 39(a)(1), the parties may also consent to a bench trial. See FRCP 39(a)(1).

60 In re Consolidated Parlodel Litigation, 182 FRD 441, 447 (D NJ 1998) (denying plaintiffs' motion for consolidation of actions stemming from injuries allegedly caused by a prescription drug).

61 In re Rhone-Poulenc Rorer, Inc, 51 F3d 1293, 1300 (7th Cir 1995). 
natively, a federal court may be able to adopt grouping and subclassing techniques to overcome any manageability concerns. Although these proposals depend on the circumstances of any given case, they at least defeat the notion that the choice-of-law problem renders a nationwide class "ipso facto" unmanageable. In light of the policies underlying Rule 23(b)(3), a federal district court should seriously consider whether these proposals would resolve the manageability concerns created by the choice-of-law problem before denying certification.

\section{A. Can a Single Law Be Applied to a Nationwide Class?}

In theory, the best way to overcome the task of instructing a jury on the laws of the fifty states is to avoid the problem altogether by applying a single law to the class. As is noted in Part I.D, there have been several creative attempts by district courts to apply a single law to a nationwide class. The Supreme Court's decision in Phillips Petroleum Co v Shutts, however, has limited the amount of judicial creativity by articulating constitutional safeguards on the choice of applicable law in nationwide class actions.

In Shutts, the Court, against the background of the Full Faith and Credit $^{63}$ and Due Process Clauses ${ }^{64}$ of the Constitution, established a twoprong test for the choice of applicable law in a nationwide class action. In Shutts, a Kansas state court certified a class action brought by lessors of gaslands against Phillips and other lessees for interest allegedly due on royalty payments. ${ }^{65}$ The class of lessors, consisting of 28,100 members, owned land in eleven states; however, less than 3 percent of the plaintiffs and 1 percent of the leases had any connection with the state of Kansas. ${ }^{66}$ Nevertheless, the Kansas court applied Kansas contract and equity law to every claim in the case. ${ }^{67}$ The U.S. Supreme Court affirmed the trial court's assertion of jurisdiction over the plaintiff class members, but reversed its application of Kansas law to the action. ${ }^{68}$ The Court declared that if there is no material conflict between the forum state's law and that of any other state, then there is no constitutional objection to the application of a single, essentially uniform, legal standard. ${ }^{69}$ However, if there is a material conflict between the laws of the respective states-that is, if variations in state law exist-a district court's selection of a single law is permissible only when the state has a "significant contact or significant

\footnotetext{
62472 US 797 (1985).

63 US Const Art IV, $\S 1$.

64 US Const Amend XIV, $\$ 1$.

65472 US at 801.

66 Id at 801, 814-15.

67 Id at 814-15.

68 Id at 823 .

69 Id at 816.
} 
aggregation of contacts, creating state interests, such that choice of its law is neither arbitrary nor fundamentally unfair.,"70

After crafting the two-pronged Shutts test, the Court proceeded to the facts of the case. Although noting that the Kansas court failed to determine adequately whether Kansas contract and equity law materially conflicted with the law of a number of states with an interest in the litigation, such as Texas and Oklahoma, the Court proceeded to base its decision on the second prong of the Shutts test. The Court held that the mere fact that Phillips Petroleum owned property and conducted business in Kansas did not constitute the minimum level of "significant contact or significant aggregation of contacts" such that Kansas had a "state interest" in the litigation, and therefore the decision to apply Kansas law to the class was "sufficiently arbitrary and unfair as to exceed constitutional limits." The Court, however, left open the possibility that a single law could be applied to a nationwide class if the Shutts test is satisfied.

\section{Constitutional restraints:The Shutts test and the significance} of contacts.

Although it may be possible to read Shutts as foreclosing the possibility of applying a single law to the claims underlying a nationwide class action, some district courts have asserted that the Court did not foreclose the possibility of the application of forum law, or the law of another state, to a nationwide class. ${ }^{2}$ While conducting business and owning property in a particular state did not constitute significant contacts in Shutts, the Court has never articulated the exact nature of the contacts that would be sufficient. As a result, district courts have assumed the task of fleshing out the nature of the contacts that would be sufficient to render the selection of a single law consistent with Shutts's constitutional limitations.

As a starting point, some commentators note that contacts sufficient to justify application of a single law must be more significant than contacts sufficient to create personal jurisdiction. ${ }^{73}$ Under the familiar test of

70 Id at 818, quoting Allstate Insurance Co v Hague, 449 US 302, 313 (1981).

$71 \quad 472$ US at 821-22.

72 See, for example, In re Lilco Securities Litigation, 111 FRD 663, 670 (E D NY 1986) ("Without doubt, Shutts does not require us to apply the law of each state in which the plaintiffs reside nor does it prohibit the application of one state's law to all plaintiffs, regardless of residence. Defendants, therefore, misread Shutts when they argue that this Court may be forced to consider the law of all fifty states.") (emphasis added).

73 See, for example, William D. Torchiana, Comment, Choice of Law and the Multistate Class: Forum Interests in Matters Distant, 134 U Pa L Rev 913, 922-23 (1986) (noting that "the consequences of reaching out to assert jurisdiction may not be as severe as the consequences of reaching out to apply forum law"). In order for personal jurisdiction to lie, a district court must have minimum contacts with the litigation. In contrast, in order for a district court to apply forum law, or a single state law, to the controversy, a district court must have significant contacts or an aggregation of contacts creating state interests such that the choice of law is neither arbitrary nor unfair. 
International Shoe Co $v$ Washington, ${ }^{74}$ a district court may exercise personal jurisdiction over a defendant if the forum has "minimum contacts" with the litigation. Yet, even after personal jurisdiction is established, a district court may not apply a single state's law to the class unless that law meets the higher threshold of "significant contacts" required by the Shutts test. ${ }^{75}$ Bootstrapping is prohibited.

There have been, however, a number of cases where a nationwide class has been able to establish the higher threshold of significant contacts such that a single state's law can be applied to the action. A number of district courts have found significant contacts to exist in the state where the defendant's principal place of business is located. ${ }^{76}$ For example, in Bunnion v Consolidated Rail Corp, " a Pennsylvania district court determined that the selection of the forum state's law to govern a nationwide class was constitutional because the defendant, Consolidated Rail Corp, incorporated and maintained its principal place of business in Pennsylvania. In addition, as the ALI's Complex Litigation Project notes, significant contacts have also been found to exist in the state of

74326 US 310 (1945).

75 Since a plaintiff may bring suit almost anywhere under Shutts's jurisdictional holding, a plaintiff should consider the significance of the contacts of the prospective forum states and their respective choice-of-law rules in selecting a forum in which to bring suit. It is imperative that a plaintiff bring a motion for class certification in a state that would support the application of a single law. If the plaintiff should mistakenly bring suit in a state that does not support the application of a single law, he should voluntarily dismiss the case pursuant to Rule 41(a). Otherwise, if the plaintiff brings an action in an inappropriate forum and afterwards seeks to transfer the action to a forum with more significant contacts, the Supreme Court's decision in Ferens v John Deere Co, 494 US 516 (1990), would require each of the transferor state's choice-of-law rules to govern the selection of the applicable law, thereby needlessly compounding the choice-of-law analysis. Id at 522-23. Of course, it may be the case that a particular plaintiff lacks the necessary resources to bring an action in the state with the requisite significance of contacts to satisfy the Shutts test. However, in a nationwide Rule 23(b)(3) class action where the cause of action itself depends on forum selection, it may be appropriate to consider the plaintiff's ability to do so as part of Rule 23(a)'s adequacy of representation analysis.

76 See Gruber v Price Waterhouse, 117 FRD 75, 82 (E D Pa 1987) (finding selection of forum law constitutional in securities litigation where defendant Price Waterhouse maintained its principal place of business in the forum and auditing and financial statement preparation occurred there); In re ORFA Securities Litigation, 654 F Supp 1449 (D NJ 1987) (applying New Jersey law to the class where defendant's principal place of business was New Jersey and alleged misrepresentations originated there); In re Activision Securities Litigation, 621 F Supp 415, 430-31 (N D Cal 1985) (selecting California law to govern a class where Activision maintained its principal place of business in the state, issued securities in the state, and the purchasers' acceptances were directed at the state). But see In re Ford Motor Co Bronco II Product Liability Litigation, 177 FRD 360, 369-71 (E D La 1997) (holding that the Shutts test was not satisfied by plaintiff's attempt to apply Michigan law to a nationwide class on the grounds that defendant Ford has its principal place of business in Michigan and design decisions were made there); Endo v Albertine, 1995 US Dist LEXIS 4517, *17 (N D Ill 1995) (holding that no significant contacts exist justifying application of Illinois law when defendant's principal place of business is located in Illinois because there is no indication that plaintiffs expected forum law to govern).

771998 US Dist LEXIS 7727 (E D Pa 1998).

78 Id at *30. 
manufacture. ${ }^{7}$ Moreover, since the significance of the requisite contacts will vary with the facts of a given case, the aforementioned examples are by no means the exclusive form of contacts sufficient to justify the application of a single law. Some aggregation of contacts, such as a deliberate and significant course of conduct, may justify applying a single law in certain circumstances. Thus, in order to promote judicial efficiency and the proper distribution of justice for small plaintiffs in a negative value suit scenario, a district court should engage in a thorough analysis of the Shutts decision to consider the possibility of a single applicable law.

\section{State choice-of-law restraints: Tying the Klaxon analysis to Rule 23.}

The Shutts analysis, however, must be informed by state choice-oflaw doctrine. In Shutts, Justice Rehnquist warned that a state may not manufacture contacts or manipulate the Klaxon analysis so as to select a single law and thereby satisfy Rule 23(b)(3)'s requirements. Although Shutts functions as a constitutional backstop against which a district court may select the law applicable to a nationwide class action, the Klaxon requirement that a federal court apply the choice-of-law methodology of the state in which it sits remains the fulcrum through which all choice-oflaw inquiries must pass. As a result, a district court may not create a theoretical legal standard out of thin air. More importantly, although a court may be able constitutionally to select a single law to apply to the class consistently with the Shutts test, the court may be foreclosed from considering such a possibility by Klaxon's obligation to apply the forum state's choice-of-law methodology.

79 ALI, Complex Litigation Project $\$ 6.01$, Reporter's Notes to Comment C (cited in note 35) (collecting cases). See also In re Benedictin Litigation, 857 F2d 290, 303-06 (6th Cir 1988) (applying the law of the state of manufacture to the class at issue).

80 Interestingly, in Clothesrigger, Inc v GTE Corp, 191 Cal App 3d 605 (1987), a California appellate court went a step further and held that it was reversible error to fail to consider the possibility of a single governing law on a motion for class certification. Id at 612 .

81 Shutts, 472 US at 821 .

82 It is important to distinguish between a district court's application of a single state's substantive law to a class pursuant to a Klaxon-Shutts analysis and a district court's creation of a single law to be applied to the class on its own initiative. For example, in Wadleigh $v$ Rhone-Poulenc Rorer, Inc, 157 FRD 410 (N D Ill 1994), a district court certified a nationwide class action brought on behalf of hemophiliacs infected with the HIV virus as a consequence of using Rhone-Poulenc's blood solid products. To finesse the tension between Rule 23 and the choice-of-law problem, the court contrived a "national amalgam" approach, which merged the negligence standards of the fifty states and the District of Columbia into a single substantive standard. In In re Rhone-Poulenc Rorer, Inc, 51 F3d 1293, 1300 (7th Cir 1995), the Seventh Circuit reversed. Judge Posner's majority opinion properly equated the district court's "esperanto" standard to the creation of federal common law, which was banished forever in Erie Railroad v Tompkins. The distinction between the former and latter applications of a single law is that the former respects state sovereignty, but reaches a compromise with interstate comity short of due process concerns. In contrast, the "national amalgam" approach is utterly divorced from any concerns with state sovereignty, comity, and due process. 
Assuming the Shutts test is met, a district court may be able to resolve the choice-of-law problem by tying the Klaxon analysis to the policies underlying Rule 23(b)(3) in order to justify the application of a single state's law to the entire class. The Klaxon analysis is a subjective inquiry requiring a balancing of loosely defined factors and ambiguous interests, and as a result, a district court retains a tremendous amount of discretion. Consequently, in interest analysis states, a district court may be able to frame the analysis of the relative interests of the various states to favor the application of a single state's law to the claims of the class as a whole.

For example, in In re Seagate Technologies Securities Litigation, a California district court, applying California's comparative impairment version of interest analysis, presented the relevant interest inquiry as a choice between a foreign state's interest in allowing their resident's legal "claims to proceed under [another state's] law-or not at all." The underlying assumption is that if the Shutts test and the Klaxon analysis truly resulted in the applicability of all fifty states' laws then a nationwide class action could never be certified and the policies underlying Rule 23 would be defeated. ${ }^{s 5}$ Therefore, the court held that a foreign state's interest in the maintenance of a class action at all outweighs its interest in the application of its own laws to its residents, and consequently, the law of the forum state should be applied. ${ }^{86}$ In this manner, a district court may refocus the Klaxon analysis on the policy of distributing greater justice to

83115 FRD 264 (N D Cal 1987). See also In re Pizza Time Theatres Securities Litigation, 112 FRD 15, 20 (N D Cal 1986) (holding that blanket application of California tort law in class action would not impair integrity of other states more than foreclosing the possibility of class action litigation altogether); In re Activision Securities Litigation, 621 F Supp 415, 430-31 (N D Cal 1985) (applying California law to a securities class action); In re ORFA Securities Litigation, 654 F Supp 1449, 1463-64 (D NJ 1987) (applying New Jersey state law to a securities class action). Although the aforementioned cases all involved the application of forum law, it is possible that a district court may be able to apply the law of another state to the class. For example, a district court may apply the law of the state of the defendant's place of business to the claims of the class as a whole, even though the district court sits in another state, based on similar reasoning.

84 See In re Seagate Technologies Securities Litigation, 115 FRD at 271 (certifying nationwide class in securities fraud action).

85 See In re Activision Securities Litigation, 621 F Supp at 438 (allowing certification of a single legal issue to promote the policies of Rule 23). As noted in Part III.B, however, the author challenges the notion that a class action proceeding under the laws of the fifty states could never be managed.

86 In re Activision Securities Litigation, 621 F Supp at 438. However, before a district court may invoke this analysis, it must confirm that the premise holds true-the potential class action should be a negative value suit such that litigation costs outweigh the potential value of unaggregated, individual claims. Moreover, even if a negative value suit is not present, a district court should consider the extent that litigation costs in general become prohibitive in Rule 23(b)(3) nationwide class actions. See McBride v Galaxy Carpet Mills, 920 F Supp 1278, 1285 (N D Ga 1995) ("[E]ven plaintiffs with claims of $\$ 100,000$ or more cannot, as a practical matter, afford to retain the expert witnesses, laboratories, and discovery documents needed to properly prosecute their claims.") (internal citations omitted). 
small plaintiffs in negative value suit scenarios, and a nationwide class may proceed without any management difficulties.

\section{B. The Grouping and Subclassing Technique}

Alternatively, if the laws of the fifty states must apply to a nationwide class, a viable method for overcoming manageability concerns remains. Modern trial management techniques, such as grouping and subclassing, make it possible for a district court to manage large, complex cases in a manner foreign to the common law. Indeed, the Federal Rules of Civil Procedure, the Manual for Complex Litigation, ${ }^{87}$ and the Civil Justice Reform Act of $1990^{88}$ all seem to encourage active experimentation with such techniques in modern complex litigation. Although it may take several years for a court to manage a Rule 23(b)(3) nationwide class action employing such techniques, the greater economies of scale, time, and effort derived by consolidating a nationwide class action in a single forum, coupled with the plaintiffs' inability to vindicate their rights without a collective action procedure, suggests that a court should give grouping and subclassing serious consideration.

1. The use of Rule 23(c)(4)(A) to isolate core issues.

In evaluating the manageability of a 23(b)(3) class action, a district court's first task should be to reduce the number of legal issues and subissues to manageable proportions. Although there is some doubt as to its constitutionality, under Rule 23(c)(4)(A), a district court is empowered to certify a class with respect to particular issues only. ${ }^{\circ}$ As the ALI's Complex Litigation Project recognizes, by isolating core issues that are common to and typical of the class members, such as general causation, negligence, failure to warn, and the defectiveness of a product, a district court may properly grant a partial nationwide Rule 23(b)(3) class certifi-

87 Federal Judicial Center, Manual for Complex Litigation (Third) §3,115-18,219-23 (West 1995) (explaining that a district court can use subclassing to cure potential obstacles to class certification).

88 Judicial Improvements Act of 1990, Pub L No 101-650, 104 Stat 5089, codified at 28 USC $\S 471$ (1994) (requiring each district court to implement a civil justice expense and delay reduction plan).

89 See Complex Litigation Project at 147 (cited in note 35) (stating that "[t]he major constitutional challenge to issue severance is whether the procedure impinges upon the parties' traditional rights to a jury trial" because uncertified individual and subsidiary issues would be tried by a different jury).

90 See Joseph Sanders, From Science to Evidence: The Testimony on Causation in the Bendectin Cases, 46 Stan L Rev 1, 73 (1993) (noting that bifurcating cases into separate issues may be one way of avoiding the problem of having factfinders grapple with complex scientific evidence in mass tort cases). But see, for example, Castano y American Tobacco Co, 84 F3d at $745 \mathrm{n} 21$ ("Severing the defendants' conduct from reliance under Rule 23(c)(4) does not save the class action. A district court cannot manufacture predominance through the nimble use of subdivision (c)(4)."). 
cation on core liability issues. ${ }^{91}$ Once the partial nationwide class action resolves the core liability issues, each class member may then employ offensive collateral estoppel on those issues in subsequent individual actions to resolve the individual issues severed at the initial stage of class certification.".

Although a plaintiff may resist the severance of issues based on the perception that severing issues produces a sterile trial, the objection begs the question whether a nationwide class in a negative value suit scenario would be better off with a sterile trial or no trial at all. Indeed, the severance of core issues in a nationwide Rule 23(b)(3) class action may achieve a more equitable equilibrium between the legitimate concerns of both plaintiffs and defendants on a motion for class certification. ${ }^{93}$

\section{The relative uniformity prediction and the grouping and subclassing technique.}

Once the subsidiary issues are severed, a district court should examine the relevant states' laws on the core liability issues with an eye towards overcoming the choice-of-law problem. The court may be surprised by what it finds. According to Larry Kramer's "relative uniformity" prediction, "there will never be fifty different substantive rules, or even fifteen or ten. States tend to copy their laws from each other, and many use identical or virtually identical rules. In practice, the court will seldom have to deal with more than three of four formulations." "Many

91 For a detailed discussion of the American Law Institute's promotion of Rule 23(c)(4)(A) issue severance and partial class certification, see Complex Litigation Project at 132-61 (cited in note 35). More specifically, for a comprehensive list of situations where issue severance and partial class certification may be useful, see Complex Litigation Project at 142-45. See also James A. O'Neal and Bridget M. Ahmann, The Use of Settlement Classes in Mass Tort Product Liability Litigation, 19 Hamline L Rev 383, 385 (1996) (noting an "emerging trend" toward carving out common issues of fact or law under Rule 23(c)(4)(A)).

92 See Parklane Hosiery Co, Inc y Shore, 439 US 322, 331 (1979) (upholding use of offensive collateral estoppel).

93 Note that a defendant may complain about the settlement pressure created by a certification of a Rule 23(b)(3) nationwide class action, see In re Rhone-Poulenc Rorer, Inc, 51 F3d 1293, 1298, 1300 (7th Cir 1995). A partial class certification may help eliminate such pressures. Indeed, an influential empirical study has noted that, although defendants win in only 42 percent of ordinary personal injury cases tried to completion, they prevail in 79 percent of cases in which core issues are severed. Maurice Rosenberg, Court Congestion: Status, Causes and Proposed Remedies, in Harry W. Jones, ed, The Courts, The Public, and the Law Explosion 29, 48 (Prentice-Hall 1965) (analyzing the numerous procedural innovations with which overburdened trial courts have experimented). Thus, a rational defendant in a high stakes class action would have little reason to fear trial and settle. At the same time, although a sterile trial may diminish a plaintiff's leverage in settlement discussions and sympathy before the jury, there is nothing inherently prejudicial about such a procedure. Moreover, plaintiffs bringing a nationwide Rule $23(\mathrm{~b})(3)$ class action, especially in negative value suit scenarios, clearly benefit more from a one in five chance of victory than from the likely situation in which no trial occurs at all.

94 Larry Kramer, Choice of Law in Complex Litigation, 71 NYU L Rev 547, 583 (1996) (downplaying the number of actual differences between different states' laws). 
district courts have wrestled with the relative uniformity prediction in a wide array of legal contexts." For example, in In re Asbestos School Litigation, ${ }^{\text {,6 }}$ the court stated:

One matter, bearing on the manageability of this litigation ... is the applicability of the state law of 54 jurisdictions. At first blush, this aspect of the litigation would seemingly prevent nationwide class certification. However, on further reflection, the problem is not nearly so complex. First, there is substantial duplication among the various jurisdictions as to the applicable law. For example, as to negligence, 51 jurisdictions are in virtual agreement in that they apply the Restatement (Second) of Torts $\S 388$. As to strict liability, the basic test is Restatement (Second) of Torts $\S 402$ (a) that one who sells a product in a defective condition unreasonably dangerous to the user is liable. Forty-seven jurisdictions have adopted strict liability theories and all of them start with the concept of a defective product. $^{\text {s7 }}$

The utility of the relative uniformity thesis is that it facilitates the ability of a district court to employ the grouping and subclassing techniques.

The grouping and subclassing techniques are essentially two alternative methods of trying a nationwide class action on the merits. In general, a district court should consider the grouping option first because of the larger economies of scale derived from proceeding as a single class. The grouping technique is a simple technique whereby a district court organizes a single class into the three or four groups of representative state law predicted by the relative uniformity thesis. The judge may then ask the jury to return separate verdicts based on the core liability issues as defined by each of the clusters of representative state law. In some circumstances, however, the grouping procedure may be foreclosed as an option. For example, although the grouping technique may solve Rule 23(b)(3)'s manageability and predominance concerns, it may frustrate Rule 23(a)'s adequacy of representation requirement. ${ }^{98}$ Since different

95 See, for example, In re General Motors Corp Pick-Up Truck Fuel Tank Products Liability Litigation, 55 F3d 768,817-18 (3d Cir 1995) (product liability); Fisher v Bristol-Myers Squibb Co, 181 FRD 365, 369 (N D Ill 1998) (same); In re Ford Motor Co Ignition Switch Products Liability Litigation, 174 FRD 332, 347-51 (D NJ 1997) (same); Bresson v Thomson McKinnon Securities Inc, 118 FRD 339,343-44 (S D NY 1988) (same); In re Lilco Securities Litigation, 111 FRD 663, 670-71 (E D NY 1986) (securities fraud); In re the Prudential Ins Co of America Sales Practices Litigation, 962 F Supp 450,525 (D NJ 1997) (consumer fraud); In re Jackson National Life Insurance Co Premium Litigation, 183 FRD 217, 222-23 (W D Mich 1998) (contract law); Sollenbarger v Mountain States Telephone and Telegraph Co, 121 FRD 417, 429 (D NM 1988) (same).

96104 FRD 422 (E D Pa 1984), affd in part, vacated in part, 789 F2d 996, 1011 (3d Cir 1986).

97 Id at 434. But see Rhone-Poulenc, 51 F3d at 1300 ("The law of negligence ... may differ among the states only in nuance.... But nuance can be important.").

98 See Arthur R. Miller and David Crump, Jurisdiction and Choice of Law in Multistate Class Actions After Phillips Petroleum Co. v. Shutts, 96 Yale L J 1, 66-67 (1986) (pointing to potential con- 
state laws may provide varying amounts of recovery, potential conflicts of interest can arise when a single attorney represents a single nationwide class as grouped.

If the grouping technique is unavailable for this reason, a district court may invoke Rule 23(c)(4)'s discretionary power to create subclasses. Under Rule 23(c)(4)(B), an unmanageable class "may be divided into subclasses and each subclass treated as a class." In Amchem Prod$u c t s$, the Supreme Court encouraged subclassing as a practical alternative when a class as a whole does not meet Rule 23(b)(3)'s requirements. ${ }^{100}$ Since a district court may provide separate representation for each subclass pursuant to Rule 23(c)(4)(B), the tension with Rule 23(a)'s adequacy of representation requirement is relieved. ${ }^{101}$ As a result, a district court may then send each of the three or four subclasses to different juries for a verdict on the core liability issues based on the representative state law of the subclass.

Thus, the grouping and subclassing techniques provide a method of organizing legal claims in order to drastically reduce, simplify, and narrow the number of legal issues at trial, thereby making the prospect of a nationwide class action seem less overwhelming at the certification stage. More specifically, the techniques allow a district court to avoid the task of instructing a jury on the laws of the fifty states. As such, a district court should seriously consider their potential for mitigating the choice-of-law problem on a case-by-case basis.

\section{Ascertainment and cluster allocation.}

The proposed grouping and subclassing technique, however, may only move beyond theory into practice if a district court possesses a coherent method of ascertaining the laws of the fifty states and assigning them to a particular cluster of state laws.

a) Ascertainment. Some commentators have suggested that a district court's ability to group and subclass claims does not reduce manageability concerns because a court cannot confirm the relative uniformity thesis without substantial initial difficulty in ascertaining the laws of the fifty states. $^{102}$ However, the assertion ignores the reality of modern complex litigation. In recent times, "every [class action] lawyer has [conducted] a

flicts of interest)

99 FRCP 23(c)(4)(B).

$100521 \mathrm{US}$ at 627.

101 Some commentators assert that subclassing results in fifty-plus sets of attorneys representing the class, imposing costs that exceed any benefits to the class. See Miller and Crump, 96 Yale L J at 66-67 (cited in note 98) (tempering "with realism" judicial subgrouping of classes). However, the argument effectively ignores the relative uniformity thesis. A district court would never need to certify fifty different subclasses and sets of attorneys; it would only need to certify a handful of subclasses represented by a small number of class counsel.

102 Miller and Crump, 96 Yale L J at 64-65 (cited in note 98). 
fifty state search at some time in his or her career."103 Once a law firm prepares a multi-state comparative analysis of a particular legal claim, the marginal cost of ascertaining the same legal issues in future nationwide class actions is quite small, especially considering that the small circle of class action attorneys tend to be repeat players. Although the litigants typically proffer such multi-state analyses of the laws on a motion for class certification, a district court should insist on its inclusion. ${ }^{104}$ Once the initial proffer of the states' laws is made, a district court may then crossreference these analyses with the growing body of independent comparative multi-state analyses, which are less likely to be skewed by adversarial bias. ${ }^{1 / 5}$ Thus, a district court has a method for reducing the task of ascertaining the meanings of the laws of the fifty states.

In addition, some commentators have expressed concern with the problem of ascertaining unsettled state law. ${ }^{106}$ However, after the Supreme Court's decision in Sun Oil Co $v$ Wortman, ${ }^{107}$ this concern has become moot. In Sun Oil, the Court held that the Constitution is violated only when clearly established foreign law conflicts with forum law and such conflict is brought to the court's attention. ${ }^{108}$ Thus, since a court is not required to consider unsettled state law, its task of ascertaining the laws of the several states is simplified. For instance, in Sollenbarger $v$ Mountain States Telephone and Telegraph $\mathrm{Co}^{109}$ a district court, relying on Sun Oil,

103 Kramer, 71 NYU L Rev at 584 (cited in note 94).

104 Indeed, in nationwide class actions, it may be appropriate to consider a class attorney's ability to proffer such a study as part of Rule 23(a)'s adequacy of representation inquiry. If the class attorney is unable to produce such an analysis for economic reasons, the class should be allowed to seek alternative representation.

105 "A substantial body of work product is being developed to update and expand upon the early multistate analyses submitted in School Asbestos and other cases, with respect to the most commonly asserted multistate claims: fraud, negligence, strict liability, conspiracy, deceptive trade practices (consumer protection statutes), and breach of warranty." Elizabeth J. Cabraser, The Road Not Taken: Thoughts on the Fifth Circuit's Decertification of the Castano Class, paper presented at ALI-ABA Course of Study, Civil Practice and Litigation Techniques in the Federal Courts (Aug 14, 1996), available on Westlaw at SB24 ALI-ABA 433, *443 n 14 (collecting references and noting that appellate opinions increasingly have begun to require pre-certification comparative legal analysis of the laws of the fifty states). See also Richard Leiter, ed, National Survey of State Laws (Gale 3d ed 1999). Presumably, major legal publication companies will soon respond to meet the demand as well.

106 See Miller and Crump, 96 Yale L J at 63-65 (cited in note 98) (linking the difficulty of ascertainment with judicial imposition of judges' policy preferences or facile assumptions that other states would accept the forum's law). As one commentator paraphrased Judge Friendly's famous euphemism, a district court presiding over a nationwide Rule 23(b)(3) class action may be required to "determine what the courts of a dozen states would think the courts of a dozen different states would think on questions about which none of the courts have thought." Barbara Ann Atwood, The Choice-of-Law Dilemma in Mass Tort Litigation: Kicking Around Erie, Klaxon, and Van Dusen, 19

Conn L Rev 9,11 (1986) (advocating a general federal choice-of-law rule).

107486 US 717 (1988).

108 Id at 731 (affirming a Kansas Supreme Court holding that defendant was liable for interest on certain previously suspended gas royalties).

109121 FRD 417 (D NM 1988) (granting plaintiffs' motion for class certification in antitrust and 
certified a multi-state class action. Since the Restatement governed the contractual issues in almost all the states, and the three states that had not ruled on the issue were deemed not to have clearly established law, the court held that the choice-of-law problem was inoperative. ${ }^{110}$ Thus, since it does not have to consider unsettled state law or a conflict not brought to its attention, a district court's ability to ascertain the laws of the several states is simplified even further. The process has become one of assimilation instead of ascertainment, and although the assimilation process "may not be fun, it is far from impossible."

b) Cluster allocation. Assuming a district court can ascertain the meanings of the laws of all fifty states, the court still needs a viable method of assigning those state laws into the three or four clusters predicted by the relative uniformity thesis. As Judge Posner recently recognized, "[t]he law of negligence ... may ... differ among the states only in nuance. But nuance can be important." "112 Since not all laws can be grouped into three or four clusters perfectly, ${ }^{113}$ the question of the effect to be given to nuances in state law is crucial to a judge's ability to group and subclass.

As noted earlier, in Shutts, the Court adopted a two-part test to restrain the application of a single state's law to a nationwide class action. "The Court sought to curb the so-called "magnet forum phenomenon." ${ }^{115}$ If a district court could automatically apply its own law to a nationwide class, the plaintiffs could shop for the forum that is most likely to return a favorable verdict or award the greatest damages. A decision binds the class, thereby frustrating the substantive policies of those states whose law could potentially have been applied to the action but which were avoided by the plaintiff's strategic choice of forum. In Shutts, the Court noted that such concerns are inoperative if the conflict between state laws is marginal. ${ }^{116}$ If there is no conflict, or the conflict is slight, a plaintiff cannot successfully forum shop. Consequently, the first prong of the Shutts test asks whether a forum's law conflicts "in any material way" with another state's law. ${ }^{17}$ If there is no material conflict, there can be no

\footnotetext{
state contract action).

110 Id at 429.

111 Kramer, 71 NYU L Rev at 582 (cited in note 94).

112 Rhone-Poulenc, $51 \mathrm{~F} 3 \mathrm{~d}$ at 1300.

113 See Walsh v Ford Motor Co, 807 F2d 1000, 1016 (DC Cir 1986) (stating that even "[t]he Uniform Commercial Code is not uniform") (internal citations omitted).

114472 US 797.

115 Id at 804. See Miller and Crump, 96 Yale $L J$ at 57-61 (cited in note 98). As Miller and Crump explain, although the Court never mentioned forum shopping explicitly, the defendants vigorousiy advanced the existence of this phenomenon to inform the Court's analysis of the Full Faith and Credit and Due Process Clauses.

116472 US at 816.

117 Id (emphasis added).
} 
constitutional injury. ${ }^{118}$ By emphasizing the materiality of a conflict, the Shutts Court implied that an immaterial conflict-a nuance-may be ignored. Thus, it should be the materiality of a conflict between the laws of the states that determines the effect to be given to a nuance in allocating such laws into the handful of clusters predicted by the relative uniformity thesis.

Notably, the Court did not proffer a methodology for resolving the scope of a material nuance. Yet, as one commentator has recognized in the reverse context, an analysis of vertical (federal-state) conflicts-of-law doctrine may aid the analysis of horizontal (state-state) choice-of-law doctrine. ${ }^{119}$ Just as a district court must determine the scope of the conflict between federal and state law in vertical choice-of-law analysis pursuant to the Erie doctrine, it should use an Erie analysis to determine the scope of the conflict between respective states' laws pursuant to the first prong of the Shutts test. Indeed, although the constitutional foundations are somewhat different, ${ }^{120}$ the central policy underlying the Supreme Court's decisions in Erie and Shutts is essentially the same-the prevention of forum shopping. ${ }^{121}$ Yet, the Erie doctrine's conflicts methodology is more completely theorized. ${ }^{12}$ At the risk of oversimplification, the basic Erie analysis is an ex ante inquiry conducted from the point of view of a litigant choosing a forum. The central question is whether the choice of law would induce a litigant to prefer one court over another in light of the "twin aims" of Erie-deterring forum shopping and inequitable administration of justice. ${ }^{123}$ Thus, since in both the Shutts and Erie contexts a

$118 \mathrm{Id}$.

119 See Joseph P. Bauer, The Erie Doctrine Revisited: How A Conflicts Perspective Can Aid The Analysis, 74 Notre Dame L Rev 1235, 1264 (1999) (suggesting horizontal conflicts analysis may aid vertical conflicts analysis).

120 Although it has no textual support, the Erie doctrine's constitutional dimension stems from the underlying principles of reserved powers "inherent in federalism and embodied in the Tenth Amendment." Richard D. Freer, Some Thoughts on the State of Erie after Gasperini, 76 Tex L Rev 1637,1645 (1998) (reassessing the "RDA prong" of the Erie doctrine in the wake of several recent Supreme Court opinions). In contrast, the constitutional dimension to horizontal choice of law is rooted in the restraints imposed by the Full Faith and Credit Clause and the Due Process Clause. See Shutts, 472 US at 816-23.

121 In Erie, the Supreme Court sought to curb the abuses of the Swift $v$ Tyson regime by relying on the twin policies of deterring forum shopping and the inequitable administration of justice. Erie, 304 US at 74-78. In Shutts, the Supreme Court was similarly concerned with curbing the horizontal "magnet forum" phenomenon-if all states adopted a similar approach, plaintiffs' attorneys would be able to identify the best plaintiffs' forum in every class action. Shutts, 472 US at 820 .

122 See Bauer, 74 Notre Dame L Rev at 1264 (cited in note 119) (recognizing that while there has been an extensive consideration of this question in the vertical setting, there has been much less discussion of it in the horizontal setting).

123 Although a bit unclear, the traditional Erie doctrine dates back to Guaranty Trust Co v York, 326 US 99, 109 (1945), where the Court held that a federal court should apply state law if failing to do so would result in a different outcome than would be reached in state court. In Hanna v Plumer, 380 US 460, 467 (1965), the Supreme Court modified the outcome determination test in dicta by tying the Erie doctrine more closely to its twin aims of forum shopping and the inequitable administration of justice and by refocusing the inquiry on the point of view of the litigant choosing a forum. 
court must resolve conflicts of law against the background of the same anti-forum-shopping policy, it is reasonable to suggest that a court transplant the more completely theorized vertical Erie analysis into the horizontal Shutts analysis.

Under a "horizontal Erie doctrine" analysis, a court endeavoring to assign the laws of the fifty states into a manageable number of clusters must compare each of the different states' laws. After identifying potential conflicts, the court should ask: From the point of view of a plaintiff initiating a nationwide Rule 23(b)(3) class action, would the nuance or nuances among the state laws in question be so significant as to render him likely to select a particular forum over another in order to benefit from the difference? If the nuance between state laws is so immaterial that a negative answer is required, a district court may place those laws in the same cluster for grouping and subclassing purposes. Since the Shutts decision contemplates a modest amount of forum shopping while the Erie doctrine leaves no room at all for forum shopping, a district court's horizontal Erie analysis of conflicts should be more flexible than in the vertical context. ${ }^{124}$ Thus, a "horizontal Erie doctrine" analysis provides district courts with a manageable test for determining the materiality of any nuances in state laws and thereby facilitates the assignment of state laws into clusters.

In re Telectronics Pacing Systems, Inc ${ }^{125}$ provides an excellent example of how the "horizontal Erie doctrine" could be used in practice. In Telectronics, a nationwide penile implant class action, the defendant attempted to set up the choice-of-law problem as a bar to class certification. The defendant argued that the laws of the fifty states would require instructing the jury on proximate cause in differing ways. For example, in Georgia and Nebraska, the courts were required to instruct the jury on proximate cause. In contrast, in California and Oklahoma, the courts no longer used the term "proximate cause." the nuance defeated certification. ${ }^{127}$ The district court, however, found that while some states may have done away with the use of the term "proximate cause" those states still instruct juries on the concept of legal causation; thus, the nuance was a "distinction without a difference."

124 See Bauer, 74 Notre Dame L Rev at 1274 (cited in note 119) (noting that "the Supreme Court has stated that federal courts sitting in diversity cases must defer to and enforce these differences [in state laws]").

125172 FRD 271 (S D Ohio 1997).

126 Id at 292.

127 Id.

128 Id. See also Elizabeth J. Cabraser, Trends and Developments in Mass Torts and Class Actions in Year One of the Post-Amchem Era, paper presented at ALI-ABA Course of Study, Civil Practice and Litigation Techniques in the Federal Courts (Aug 19,1998), available on Westlaw at SD15S ALIABA 77, *99. But see Haley $v$ Medtronic, Inc, 169 FRD 643 (CD Cal 1996). In Haley, the plaintiffs argued that state laws on negligence are quite similar, a proposition buttressed by Judge Kelly's statement in In re Asbestos School Litigation. See Haley, 169 FRD at 653. Regardless, the district 
Alternatively, the Telectronics court could have conducted a horizontal Erie doctrine analysis. The court likely would have concluded that a plaintiff would not choose a particular forum solely based on whether or not a jury hears the word "proximate cause." Since forum shopping concerns would thus be inoperative, the applicable state laws of California, Oklahoma, Georgia, and Nebraska could be clustered together for grouping and subclassing purposes without any constitutional injury.

Moreover, since a horizontal Erie doctrine places great emphasis on whether a nuance would be perceived by a litigant to affect the outcome of a trial, it is interesting to note that the seeds of the horizontal Erie doctrine framework are already latent in the case law. For example, in In re Complaint of Bankers Trust $\mathrm{Co},{ }^{120}$ the Third Circuit held that a material conflict must have a significant effect on the outcome of the trial in order to present an actual conflict in terms of choice of law. ${ }^{130}$ Similarly, in Phillips Petroleum Co $v$ Shutts, ${ }^{131}$ Justice Stevens's opinion distinguished Home Insurance Co v Dick ${ }^{132}$ and John Hancock Mutual Life Insurance Co $v$ Yates $^{133}$ on the ground that they presented clear and dispositive interstate legal conflicts. ${ }^{134}$ In both these instances, the emphasis on whether a conflict affects the outcome of a case reflects the horizontal Erie doctrine's concern with whether the litigant is likely to forum shop to benefit from a nuance. If the nuance is unlikely to have an effect on the outcome of the trial, the plaintiff has no incentive to forum shop. Therefore, Judge Posner's assertion that nuance can be potentially significant is correct; ${ }^{135}$ but under the horizontal Erie doctrine, a district court should allow a nuance to frustrate the grouping of state laws into a particular cluster only when it is significant.

\section{Specialized verdicts.}

Once a district court has employed the horizontal Erie doctrine to assign the laws of the several states into clusters, the judge, with the help of counsel, may craft specialized jury verdicts pursuant to Rule 49(a). Such verdicts can be tailored to the factual issues relevant to each of the

court stated that "the problems and complexities raised by having to consider so many different state laws-even if they are relatively the same-convince [us] that class certification would be inappropriate." Id (emphasis added). The district court did not even conduct a choice-of-law analysis, stating only that "no matter how similar-or comparable-each state's law on negligence may be, it is clear ... that the negligence laws of the fifty states have some differences." Id (emphasis added).

129752 F2d 874 (3d Cir 1984).

130 Id at 882 ("Any differences in India's laws and Pennsylvania's laws must have a significant effect on the outcome of the trial in order to present an actual conflict in terms of choice of law.") (emphasis added).

131472 US at 797.

132281 US 397 (1930).

133299 US 178 (1936).

134 Shutts, 472 US at 838 n 20 (Stevens dissenting).

135 Rhone-Poulenc, $51 \mathrm{~F} 3 \mathrm{~d}$ at 1300. 
respective clusters of law. Since a specialized verdict allows a jury to record findings on each issue of fact, ${ }^{156}$ it eliminates the need for "explanations of legal issues or hypothetical instructions demonstrating how to apply the law to [a given set of] facts." ${ }^{137}$ A judge may then take the jury's findings of fact and apply them to the clusters. ${ }^{138}$ Consequently, this aspect of the manageability analysis should be focused on the judge's ability to apply the jury's findings of fact to the respective clusters of law. The specialized verdict is the final tool necessary to avoid the impossible task of instructing a jury on the laws of the fifty states. ${ }^{139}$

The specialized verdict also negates the perhaps natural tendency for jurors to average damages claims. In nationwide Rule 23(b)(3) class actions, jurors may be troubled by the fact that differing clusters of state laws necessarily result in differing recoveries for members of the same class because of the amount and scope of damages available under state law. Since class members often have identical injuries, the jury may perceive unfairness and average the damage awards across class members. The specialized verdict, however, allows the judge, who has a more sophisticated understanding of our federal system, ${ }^{140}$ to avoid juror nullification of the law.

\section{CONCLUSION}

The adoption of Rule 23 demonstrates a commitment to providing all litigants, regardless of the size of their claims, an opportunity to have their day in court. In addition, Rule 23 saves valuable judicial resources by consolidating thousands of claims that would otherwise be tried separately across the country. In recent years, the choice-of-law problem in

136 See Manual for Complex Litigation $\$ 22.451$ at 156-58 (cited in note 87).

137 See Elizabeth A. Faulkner, Using the Special Verdict to Manage Complex Cases and Avoid Compromise Verdicts, 21 Ariz St L J 297, 314 (1989).

138 See Kramer, 71 NYU L Rev at 585 (cited in note 94).

139 In addition, the specialized verdict may help jurors organize their deliberations, simplify jury instructions, facilitate partial verdicts, isolate issues for appellate review, and reduce the costs and burden of retrial. See Manual for Complex Litigation \$22.451 at 156-57 (cited in note 87).

140 Some commentators have maintained that class actions based on the varying laws of the several states raise fairness concerns because the principle that persons similarly situated ought to receive similar treatment is violated. See Juenger, $1989 \mathrm{U}$ Ill L Rev at 122 (cited in note 35). Moreover, some commentators lament that such a situation creates inconsistent results amongst the class, which leads to public dissatisfaction with the judicial system. See Bird, Note, 96 Yale L J at 1086-88 (cited in note 37). However, such externalities are merely a product of our federal system. "Choice of law defines the parties' rights. States differ about what those rights should be. Such differences are what a federal system is all about. They are not a 'cost' of the system; they are not a flaw in its operation. They are its object, something to be embraced and affirmatively valued." Kramer, 71 NYU L Rev at 579 (cited in note 94).

141 Similarly, the specialized verdict may further assuage Judge Posner's concern that a district court's certification of a nationwide class creates enormous settlement pressure on the defendants. See Rhone-Poulenc, 51 F3d at 1298-1300. Eliminating the risk of the erroneous or runaway jury in high-stakes class actions gives the defendant one less reason to fear trial and settle prematurely. 
nationwide Rule 23(b)(3) class actions has frustrated these policies. This Comment offers a systematic framework for overcoming the choice-oflaw problem in certain circumstances. It offers a number of legitimate ways to avoid the daunting task of applying the laws of the fifty states to each class member's individual claims. Using these methods, a district court should be able to certify a nationwide Rule 23(b)(3) class action in a wide variety of circumstances. 


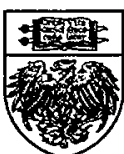

